\title{
Responses of dairy cows with divergent residual feed intake as calves to metabolic challenges during midlactation and the nonlactating period
}

\author{
K. DiGiacomo, ${ }^{* 1}$ E. Norris, ${ }^{*}$ F. R. Dunshea, ${ }^{*}$ B. J. Hayes, †‡ L. C. Marett,§ W. J. Wales,§ and B. J. Leury* \\ ${ }^{*}$ Faculty of Veterinary and Agricultural Sciences, The University of Melbourne, Parkville, Victoria, Australia, 3010 \\ †Department of Economic Development, Jobs, Transport and Resources, Agriculture Victoria, Bundoora, Victoria, Australia, 3083 \\ $\ddagger$ Queensland Alliance for Agriculture \& Food Innovation, University of Queensland, Brisbane, Queensland, Australia 4072 \\ §Department of Economic Development, Jobs, Transport and Resources, Agriculture Victoria, Ellinbank, Victoria, Australia, 3820
}

\begin{abstract}
Residual feed intake (RFI) is defined as the difference between the actual and expected feed intake required to support animal maintenance and growth. Thus, a cow with a low RFI can obtain nutrients for maintenance and growth from a reduced amount of feed compared with a cow with a high RFI. Variation in RFI is underpinned by a combination of factors, including genetics, metabolism, thermoregulation and body composition; hypothalamic-pituitary-adrenal (HPA) axis responsiveness is also a possible contributor. Responses to 3 metabolic challenges were measured in lactating and nonlactating dairy cattle. Sixteen Holstein Friesian cows with phenotypic RFI measurements that were obtained during the growth period (188-220 d old) were grouped as either low-calfhood RFI $(\mathrm{n}=8)$ or high-calfhood RFI $(\mathrm{n}=8)$. An ACTH $(2 \mu \mathrm{g} / \mathrm{kg}$ of body weight $)$, insulin $(0.12 \mathrm{U} / \mathrm{kg}$ ), and epinephrine (a low dose of $0.1 \mu \mathrm{g} / \mathrm{kg}$ and a high dose of $1.6 \mu \mathrm{g} / \mathrm{kg}$ of epinephrine) challenge were each conducted during both midlactation (122 \pm $23.4 \mathrm{~d}$ in milk) and the nonlactating period (dry period; approximately $38 \mathrm{~d}$ after cessation of milking). Cows were housed in metabolism stalls for the challenges and were fed a diet of alfalfa cubes ad libitum for at least $10 \mathrm{~d}$ before the experiment (lactating cows also were offered a total of $6 \mathrm{~kg}$ of dry matter/d of crushed wheat grain plus minerals fed as $3 \mathrm{~kg}$ of dry matter at each milking) and were fasted for $12 \mathrm{~h}$ before the challenges. The efficiency of conversion of feed into milk (the ratio of feed consumed to milk produced over the $7 \mathrm{~d}$ before the experiment) during midlactation was better (lower) in low-calfhood RFI cows, although dry matter intake did not differ between RFI groups. Low-calfhood RFI cows exhibited a lower plasma cortisol response to the
\end{abstract}

Received January 8, 2017.

Accepted February 23, 2018.

${ }^{1}$ Corresponding author: kristyd@unimelb.edu.au
ACTH challenge than high-calfhood RFI cows, particularly in midlactation $(-15 \%)$. The low-calfhood RFI cows had a greater plasma insulin-like growth factor-1 response to the insulin challenge and plasma fatty acid response to epinephrine compared with the high-calfhood RFI cows. These data suggest that high-calfhood RFI cows exhibit a more responsive HPA axis. As divergence in RFI measured during growth is retained (although reduced) during lactation, it is possible that energy is used to respond to HPA axis activation at the expense of production in high-calfhood RFI dairy cattle during lactation and contributes to a decrease in overall feed use efficiency.

Key words: cortisol, hypothalamic-pituitary-adrenal (HPA) axis, residual feed intake (RFI), efficiency

\section{INTRODUCTION}

The efficiency of conversion of feed to products (such as milk or meat) by an animal is influenced by a combination of genetic, physiological, and environmental factors resulting in individual variation in energy expenditure. Residual feed intake (RFI) is the difference between an animal's actual and expected feed intake that reflects the inherent metabolic differences between animals, as demonstrated in beef cattle by Archer et al. (1999). Based on this metric, animals of low RFI are more feed efficient than those of high RFI. The measurement of RFI is complicated in dairy cows by dynamic changes to BW, gut fill, and body composition as lactation progresses. As lactation causes many changes in energy partitioning, the measurement of RFI in growing heifers rather than lactating cows is potentially more reliable, practical, and cost effective (Williams et al. 2011; Waghorn et al., 2012; Pryce et al., 2012). Genomic predictions of RFI in HolsteinFriesian cows have been developed (Pryce et al., 2012) and evidence has shown that selection for RFI in growing animals is correlated with RFI in lactating animals (Nieuwhof et al., 1992; Macdonald et al., 2014). In beef cattle, feed efficiency is influenced (in part) by behav- 
ioral processes, such as stress responsiveness, as well as differences in efficiency of digestion, heat production, body composition, and activity between individual animals (Herd et al., 2004).

Dairy cattle are regularly exposed to a variety of acute and chronic stressors such as social (e.g., social hierarchy), physiological (e.g., confinement), and environmental stressors. One of the major biological responses to stress is the activation of the hypothalamic-pituitaryadrenal (HPA) axis, which leads to the release of cortisol from the adrenal cortex (Selye, 1951); this results in the catabolism of energy stores to provide glucose. Cortisol production also affects several metabolic and physiological processes, such as increased cardiovascular tone, immune system activation, appetite modulation, and reduced reproductive function (Sapolsky et al., 2000). Lactating animals display reduced neuroendocrine responses to HPA axis activation compared with nonlactating animals (Tilbrook and Clarke, 2006). The use of exogenous hormones to stimulate metabolic responses and distinguish variations in physiological processes, such as those associated with feed efficiency and energy use, is well documented (Sechen et al., 1990; Boisclair et al., 1997; Jenkins et al., 2013). Equivalent techniques have been used to demonstrate relationships between RFI and HPA axis responsiveness in rams using the cortisol response to ACTH (Knott et al., 2008, 2010). In rams, between 17 and $40 \%$ of the variation in RFI could be attributed to changes in cortisol concentrations following administration of ACTH (Knott et al., 2008, 2010). Animals that are more responsive to stress hormones may have a greater energetic cost of maintaining homeostasis than less-responsive animals, and this may occur at the expense of production.

This experiment used cows selected based on phenotypic RFI measured as calves, which is demonstrated to be maintained from growth into lactation (Macdonald et al., 2014). It was designed to investigate variation in HPA axis responsiveness during both the lactating and nonlactating (dry) periods to discern a portion of the metabolic processes underpinning improved efficiency in animals selected based on RFI. It was hypothesized that when compared with high-calfhood RFI (less efficient) cows, low-calfhood RFI (more efficient) cows would have a decreased HPA axis response, characterized by (1) low-calfhood RFI having a decreased plasma cortisol response to an ACTH challenge, (2) decreased insulin sensitivity, and (3) greater responses to an epinephrine challenge. It was also hypothesized that cows of high- and low-calfhood RFI in different physiological states (midlactation and nonlactating) would have similar variation in the responses to the ACTH, insulin, and epinephrine challenges.

\section{MATERIALS AND METHODS}

\section{Cows and Management}

This experiment was conducted at the Department of Economic Development, Jobs, Transport and Resources' Ellinbank Centre in Victoria, Australia (latitude $38^{\circ} 14^{\prime} \mathrm{S}$, longitude $145^{\circ} 56^{\prime} \mathrm{E}$ ). All procedures were approved by the Department of Economic Development, Jobs, Transport and Resources Animal Ethics Committee.

Sixteen Holstein-Friesian cows of second and third parity were selected from a larger herd of animals $(\mathrm{n}=$ 903) that were previously evaluated for phenotypic RFI during calfhood (Williams et al., 2011), as divergence in RFI for growth is retained (although reduced) during lactation (Macdonald et al., 2014). Briefly, during the RFI measurement period Holstein-Friesian heifer calves (188-220 d old; 179-224 kg) were penned in groups of 15 to 20 and fed a diet of alfalfa hay cubes ad libitum for up to $95 \mathrm{~d}$. Individual measures of weight (1-2 times per week) and feed intake (daily) were obtained for a measurement period of at least $60 \mathrm{~d}$ postacclimation, as described by Williams et al. (2011). Individual animal RFI was then calculated using the model

$$
\begin{aligned}
\mathrm{RFI} & =\mathrm{DMI}-(\mu+\mathrm{BW}+\mathrm{BW} \Delta \\
& \left.+ \text { farm }+ \text { age }+\mathrm{age}^{2}\right),
\end{aligned}
$$

where $\mu=$ the overall mean effect, $\mathrm{BW}=$ body weight at the midpoint, $\mathrm{BW} \Delta=$ growth rate, farm $=$ farm where heifers were sourced, and age $=$ heifer age $(d)$. Of the 903 calves measured for RFI during growth, 120 were purchased and transferred to the research farm. Those purchased were in the top or bottom $10 \%$ for RFI as calves.

For the current experiment, 8 animals were selected for high-calfhood RFI (mean RFI $=0.69 \pm 0.187 \mathrm{DM}$ $\mathrm{kg} / \mathrm{d}$ ) and 8 for low-calfhood RFI (mean RFI $-0.83 \pm$ $0.294 \mathrm{DM} \mathrm{kg} / \mathrm{d}$ ). Each cow was weighed daily (after milking during midlactation) for $10 \mathrm{~d}$ before the experiment using walk-over scales. Each cow was assessed for BCS on 3 separate days using an 8-point scale (as described by Dairy Australia, 2013), where body condition is visually scored and BCS 1 is extremely thin, BCS 4.5-5.5 is ideal at calving, and BCS 8 is extremely fat. During the dry period challenge, 3 cows were not pregnant whereas the remaining 13 cows ranging from 124 to $195 \mathrm{~d}$ pregnant. Two sets of intravenous challenges were performed on each cow; 1 during midlactation (122 \pm 23 DIM) and 1 approximately $38 \mathrm{~d}$ after being dried off using elaclox DCX teat seal (Norbrook Laboratories Australia PTY Ltd., Tullamarine, Victoria, Australia). 
Of the 16 cows, 2 low-RFI and 1 high-RFI cows were not pregnant at the time of the dry period challenge.

Cows were individually fed compressed alfalfa cubes ad libitum in individual feed bins for at least $2 \mathrm{wk}$ before the challenges. During midlactation, each cow was also offered $6 \mathrm{~kg}$ of DM as crushed wheat grain (plus minerals) fed in the dairy at milking (3 kg of DM/ milking). The $\mathrm{CP}$ concentration of the total diet was approximately $18 \%$ and the estimated ME content was $10.5 \mathrm{MJ} / \mathrm{kg}$ of DM. During lactation, cows were milked twice daily at approximately 0700 and $1500 \mathrm{~h}$. Milk yield was measured at each session using a DeLaval Alpro milk metering system (DeLaval International, Tumba, Sweden). Milk samples were obtained 4 times the week before the experiment (2 from each of the a.m. and p.m. milkings), and concentrations of fat, protein, and lactose were measured using an infrared milk analyzer (model 2000, Bentley Instruments, Chaska, MN). The equation of Tyrrell and Reid (1965; eq. 2) was used to calculate ECM:

$$
\begin{gathered}
\mathrm{ECM}(\mathrm{kg})=[\text { milk yield }(\mathrm{kg}) \\
\times(376 \times \text { fat } \%+209 \times \text { protein } \%+948)] / 3,138 .
\end{gathered}
$$

\section{Challenge Protocol and Blood Sampling}

On d 1, each cow was fitted with an indwelling jugular catheter under local anesthesia, and these were immediately flushed with $10 \mathrm{~mL}$ of heparinized saline (100 $\mathrm{IU} / \mathrm{L})$. On d 2 to 4, each cow was moved into a metabolism stall at approximately $0700 \mathrm{~h}$ and allowed to settle for at least $30 \mathrm{~min}$. Cows were previously adapted to the barn and trained to enter the metabolism stalls before the experiment. Water was available at all times and feed was removed from cows $12 \mathrm{~h}$ before the challenge. On d 2, an ACTH challenge was administered. The ACTH (Synacthen, Novartis, Macquarie Park, Australia). A $2-\mu \mathrm{g} / \mathrm{kg}$ of BW dose was selected based on the findings of Verkerk et al. (1994) and was infused at approximately $0830 \mathrm{~h}$; blood samples were collected into a tube containing lithium heparin at $-45,-30$, $-15,-1,5,10,15,20,25,30,45,60,75,90,120$, 150,180 , and $210 \mathrm{~min}$ relative to the infusion. On d 3 , an insulin (Actrapid, human insulin, Novo Nordisk Pharmaceuticals Pty Ltd., Baulkham Hills, NSW, Australia. $0.12 \mathrm{U} / \mathrm{kg}$ of $\mathrm{BW}$ ) challenge was conducted with samples collected at $-30,-1,5,10,15,20,25,30,35$, $40,45,50,55,60,65,70,75,80,85,90,95,100,105$, $110,115,120,150,180,210,240,270$, and $300 \mathrm{~min}$ relative to the insulin infusion. On $\mathrm{d} 4$, an epinephrine challenge was conducted using 2 doses of epinephrine (a low dose of $0.1 \mu \mathrm{g} / \mathrm{kg}$ of epinephrine and a high dose of $1.6 \mu \mathrm{g} / \mathrm{kg}$ of epinephrine, given as adrenaline acid tartrate 1:1,000; AstraZeneca, Macquarie Park, NSW, Australia; based on the findings of Sechen et al., 1990) to measure sensitivity and responsiveness, respectively. Blood samples were obtained at $-30,-15,-1,2,4,6$, $8,10,12,15,18,20,23,26,30,35,40,50,60,90,105$, and $120 \mathrm{~min}$ relative to the low-dose infusion; after the sample, at $120 \mathrm{~min}$, the higher $(1.6 \mu \mathrm{g} / \mathrm{kg})$ dose was given and samples obtained at the same time intervals as per the low dose. During each challenge, catheters were flushed with approximately $5 \mathrm{~mL}$ of $50 \mathrm{IU}$ heparinized saline to fill the catheter dead space after each sample collection and flushed with $10 \mathrm{~mL} 1$ of $00 \mathrm{IU} / \mathrm{L}$ heparinized saline at the end of each challenge period. Blood samples were immediately placed on ice and centrifuged within $60 \mathrm{~min}$ at $1,000 \times g$ for $10 \mathrm{~min}$ at $4^{\circ} \mathrm{C}$. Isolated plasma was collected and stored at $-20^{\circ} \mathrm{C}$ before analyses.

All plasma samples were analyzed in duplicate. Plasma cortisol concentrations were measured using the method of Bocking et al. (1986). Plasma fatty acid concentrations were measured using a kit assay (Wako C NEFA kit, Novachem, Heidelberg West, Victoria, Australia; as modified by Johnson and Peters, 1993) and absorbance was measured on a Thermo Multiskanner plate reader (Thermo Fisher Scientific, Vantaa, Finland). Plasma glucose concentrations were measured as described by Trinder (1969) using the Infinity glucose oxidase liquid stable reagent (Thermo Scientific, Noble Park, Victoria, Australia) and absorbance was measured on a Thermo Multiskanner plate reader. Plasma IGF-1 was measured on basal samples only using the chloramine- $\mathrm{T}$ radioimmunoassay method described by Gluckman et al. (1983), interference by binding proteins was minimized using the acid-ethanol cryoprecipitation method validated for ruminants by Breier et al. (1991). Plasma somatotropin (ST) concentration was measured using a double antibody RIA using a standard (NIDDK oST 1-5; produced in the laboratory, details in Downing et al., 1995) and measured on a gamma counter (Roche et al., 2008). The intra- and interassay coefficients of variation were 1.6 and $0.2 \%$ for cortisol, 7.6 and $9.1 \%$ for fatty acids, 9.4 and $11.5 \%$ for glucose, 3.9 and $9.0 \%$ for IGF-1, and $6.0 \%$ and $4.3 \%$ for ST, respectively.

Plasma hormone and metabolite responses were analyzed for area under the curve (AUC) using a linear trapezoidal summation between successive pairs of metabolite concentrations after correcting for baseline concentrations. Timeframes for AUC calculations were measured over the same period for each animal and are as reported in text, chosen either to capture the peak response to the individual challenge or to report the responses for the duration of the challenge. Baseline concentrations were calculated as the mean of the samples obtained before infusion. Maximum values 
were calculated for each cow and mean values reported for each specific treatment group. Mean plasma concentrations presented are the overall mean irrespective of sample time.

\section{Statistical Analysis}

Plasma hormone and metabolite responses were subjected to the REML analysis function suitable for repeated measures in GenStat (15th edition, VSN International Ltd., Hemel Hampstead, UK) to compare the responses measured in midlactation compared with the dry period, with the main fixed factors used being RFI group, time (relative to infusion), and stage of lactation and with animal as the random factor. Parity was deemed to be nonsignificant and was not included in further analysis. Statistical analysis of AUC responses were undertaken using REML, using RFI group and stage of lactation as the main factor and the random effects of parity and individual cow. Homogeneity of resultant hormone and metabolite data was tested by generating residual plots and heterogeneous data (plasma cortisol response to ACTH; plasma glucose, fatty acid, cortisol and ST responses to insulin; and plasma glucose and fatty acid responses to epinephrine) were log-transformed before statistical analysis. Reported values were back-transformed and raw data are presented in all figures. All results presented are predicted means \pm standard error of differences (SED). Data reported as basal or time 0 are the mean of each of the baseline samples collected. Data reported as mean are the overall mean concentration of samples obtained after baseline (time 0), irrespective of sample time and stage of lactation. The data presented include the data collected from the nonpregnant cows, as this was determined not to have a significant effect. The data were assessed for effects of parity (data not presented), as these were not significant, they are not included in the presented analysis. Significance was declared at $P<$ 0.05. Nonsignificant responses or interactions are not reported.

\section{RESULTS}

\section{Intake and Milk Production}

Mean BW, BCS, and DMI did not differ between calfhood RFI groups during both midlactation and the dry period (Table 1). Milk yield, ECM yield, and milk fat and lactose percentage did not differ between RFI groups for the $7 \mathrm{~d}$ before the experiment during midlactation (Table 1). Milk protein percentage tended to be lower for the low- than the high-calfhood RFI cows (Table $1 ; P=0.07)$. The efficiency of feed conversion to milk $(P=0.03)$ and ECM $(P=0.04)$ produced over the $7 \mathrm{~d}$ before the experiment during midlactation was better for the low-calfhood RFI cows than the high-RFI cows (Table 1).

\section{Basal Concentrations of Plasma Metabolites and Hormones}

Mean basal plasma metabolite and hormone concentrations overall across the 3 challenge days are presented in Table 2. Basal plasma IGF-1 concentration was lower for low-RFI compared with high-RFI cows (20.9 vs. $23.5 \pm 0.96 \mathrm{ng} / \mathrm{mL}, P=0.04$ ). Basal plasma cortisol and ST concentrations were greater and IGF-

Table 1. Midlactation intake and production data in dairy cows classified as low-calfhood RFI ( $\mathrm{n}=8$; RFI $=-0.83)$ or high-calfhood RFI $(\mathrm{n}=8$; RFI $=0.69)$ based on phenotypic residual feed intake $(\mathrm{RFI})$ measured during growth

\begin{tabular}{|c|c|c|c|c|}
\hline Item & $\begin{array}{c}\text { Low-calfhood } \\
\text { RFI }\end{array}$ & $\begin{array}{l}\text { High-calfhood } \\
\text { RFI }\end{array}$ & $\begin{array}{l}\text { SE of the } \\
\text { difference }\end{array}$ & $P$-value \\
\hline \multicolumn{5}{|l|}{ Dry period } \\
\hline $\mathrm{BW}(\mathrm{kg})$ & 588.5 & 591.1 & 22.1 & 0.91 \\
\hline $\mathrm{BCS}$ & 4.4 & 4.4 & 0.07 & 0.76 \\
\hline $\mathrm{DMI}(\mathrm{kg} / \mathrm{d})$ & 18.1 & 18.8 & 0.94 & 0.50 \\
\hline \multicolumn{5}{|l|}{ Midlactation } \\
\hline $\mathrm{BW}(\mathrm{kg})$ & 584.7 & 594.0 & 18.9 & 0.63 \\
\hline BCS & 4.6 & 4.6 & 0.07 & 0.99 \\
\hline DMI (kg/d) & 24.8 & 25.4 & 1.14 & 0.59 \\
\hline Milk yield $(\mathrm{kg})$ & 29.3 & 26.4 & 2.61 & 0.29 \\
\hline ECM yield (kg) & 28.8 & 26.8 & 1.81 & 0.28 \\
\hline Feed:milk ${ }^{1}$ & $\begin{array}{r}20.0 \\
0.85\end{array}$ & $\begin{array}{r}20.0 \\
0.96\end{array}$ & $\begin{array}{l}1.01 \\
0.075\end{array}$ & $\begin{array}{l}0.00 \\
0.03\end{array}$ \\
\hline Feed:ECM & 0.86 & 0.95 & 0.061 & 0.04 \\
\hline Fat $(\%)$ & 4.07 & 4.17 & 0.349 & 0.77 \\
\hline Protein (\%) & 3.06 & 3.35 & 0.146 & 0.07 \\
\hline Lactose (\%) & 5.06 & 5.17 & 0.077 & 0.15 \\
\hline
\end{tabular}

${ }^{1}$ Feed:milk was calculated as kg of DMI:kg of milk per day. 
I concentration lower during midlactation compared with the dry period (cortisol $=10.2$ vs. $5.3, \pm 0.76$ $\mathrm{nmol} / \mathrm{L}, P<0.001 ; \mathrm{ST}=4.5$ vs. $3.1 \pm 0.49 \mathrm{ng} / \mathrm{mL}$, $P=0.01 ;$ IGF-I $=13.6$ vs $30.8 \pm 0.95 \mathrm{ng} / \mathrm{mL}, P<$ 0.001 , respectively). We noted an interaction between calfhood RFI and stage of lactation such that basal plasma IGF-1 concentrations were greater during the dry period and were greater for high-calfhood RFI cows during midlactation $(P=0.03)$.

\section{ACTH Challenge}

Results of each of the metabolic challenges are presented in Table 3. Figure 1A shows that plasma cortisol increased rapidly in response to $\mathrm{ACTH}$, peaking earlier and remaining elevated for longer in midlactation compared with the dry period, with an interaction between time and stage of lactation $(P<0.001)$. Low-calfhood RFI cows had lower mean plasma cortisol concentration $(P=0.04)$ and tended to have lower peak plasma cortisol $(P=0.07)$ than high-calfhood RFI cows.

Plasma fatty acid concentrations increased in response to ACTH administration, peaking at around 15 min postinjection (Figure 1B; $P<0.001$ ). The fatty acid AUC from 0 to 30 min tended to be greater in low-calfhood RFI cows during mid lactation, whereas the reverse occurred during the dry period $(P=0.06)$. Plasma glucose responses to the ACTH infusion were minimal (hence peak plasma glucose responses are not presented) but was greater during midlactation compared with the dry period (Figure $1 \mathrm{C} ; P<0.001$ ).

\section{Insulin Challenge}

Plasma cortisol concentration increased from 30 and 45 min postinfusion during midlactation and the dry period respectively, peaking at $60 \mathrm{~min}$ postinfusion (Figure 2A). The plasma cortisol AUC from 0 to 30 min in response to insulin was greater for low- compared with high-calfhood RFI cows $(P<0.01)$, and we found an interaction between group and stage of lactation $(P<0.01)$.

Plasma glucose concentration decreased to a nadir at approximately $30 \mathrm{~min}$ postinfusion, before returning to basal concentration at approximately $180 \mathrm{~min}$ postinfusion (Figure 2C). High-calfhood RFI cows had a greater plasma glucose concentration than the low-calfhood RFI cows in response to insulin, although this was only present during midlactation $(P=0.02)$.

Plasma fatty acid concentrations decreased in response to the insulin infusion and then increased from approximately $30 \mathrm{~min}$ postinfusion (Figure 2B). Mean plasma fatty acid response to insulin was lower for lowcompared with high-calfhood RFI cows during midlac-

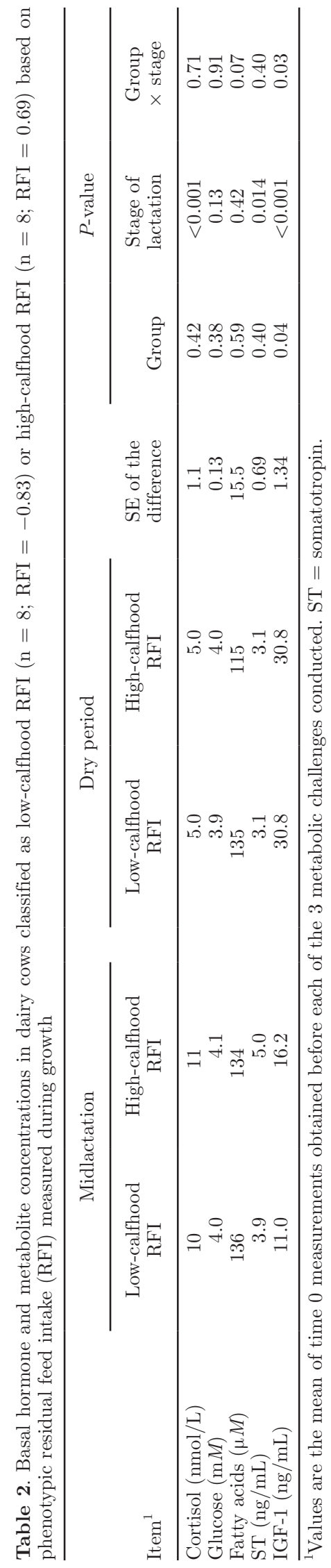




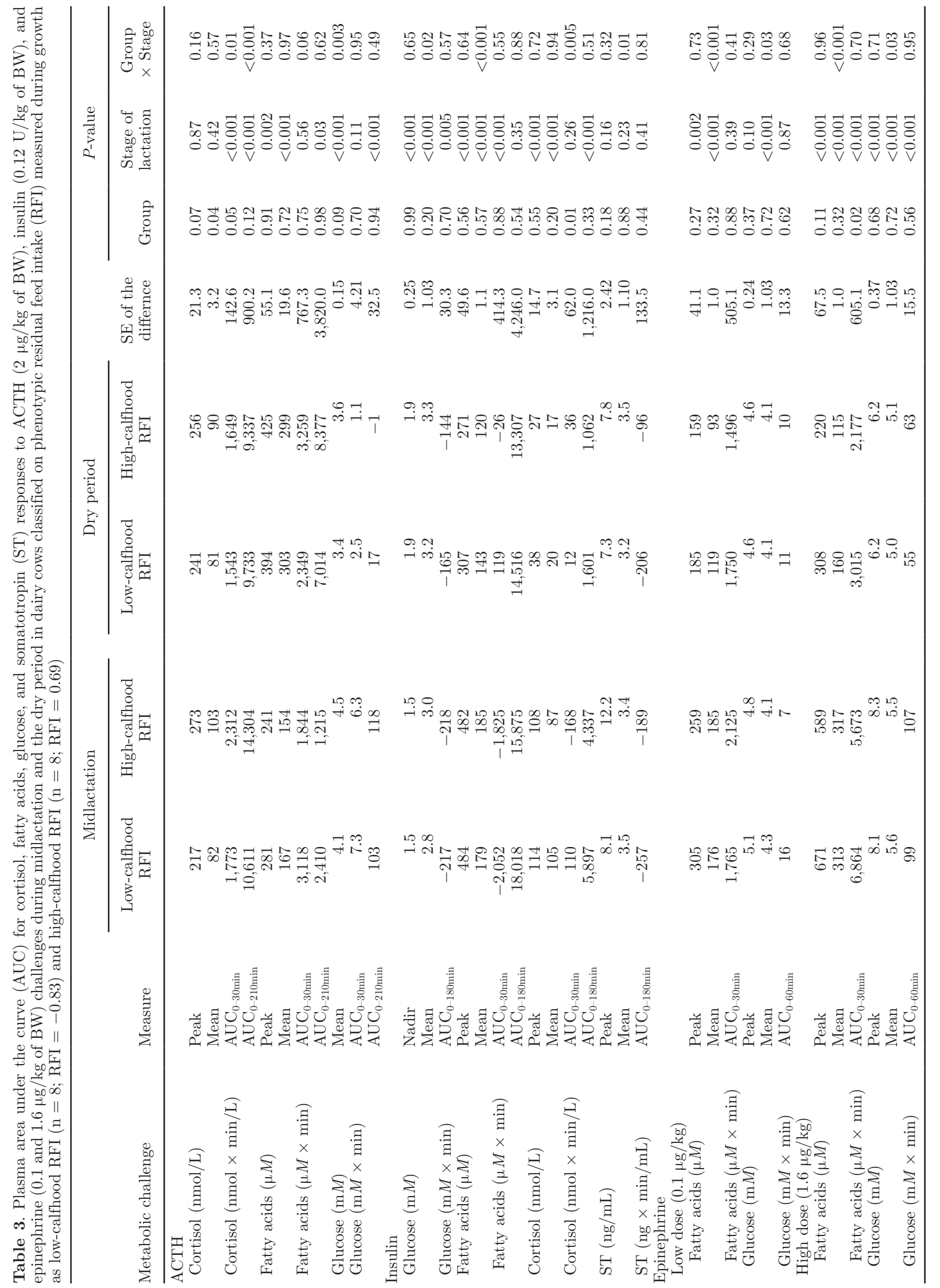


tation, but greater for low-calfhood RFI cows during the dry period $(P<0.001)$.

Plasma ST concentration increased in response to the insulin infusion (Figure 2D; $P<0.001$ ) reaching a peak concentration at 25 to 30 min postinfusion. We observed an interaction such that mean plasma ST concentrations were greater for high- compared with low-calfhood RFI cows during the dry period but not midlactation $(P=0.01)$.

\section{Epinephrine Challenge}

Mean plasma fatty acid responses were greater in response to the high epinephrine dose than the low dose,
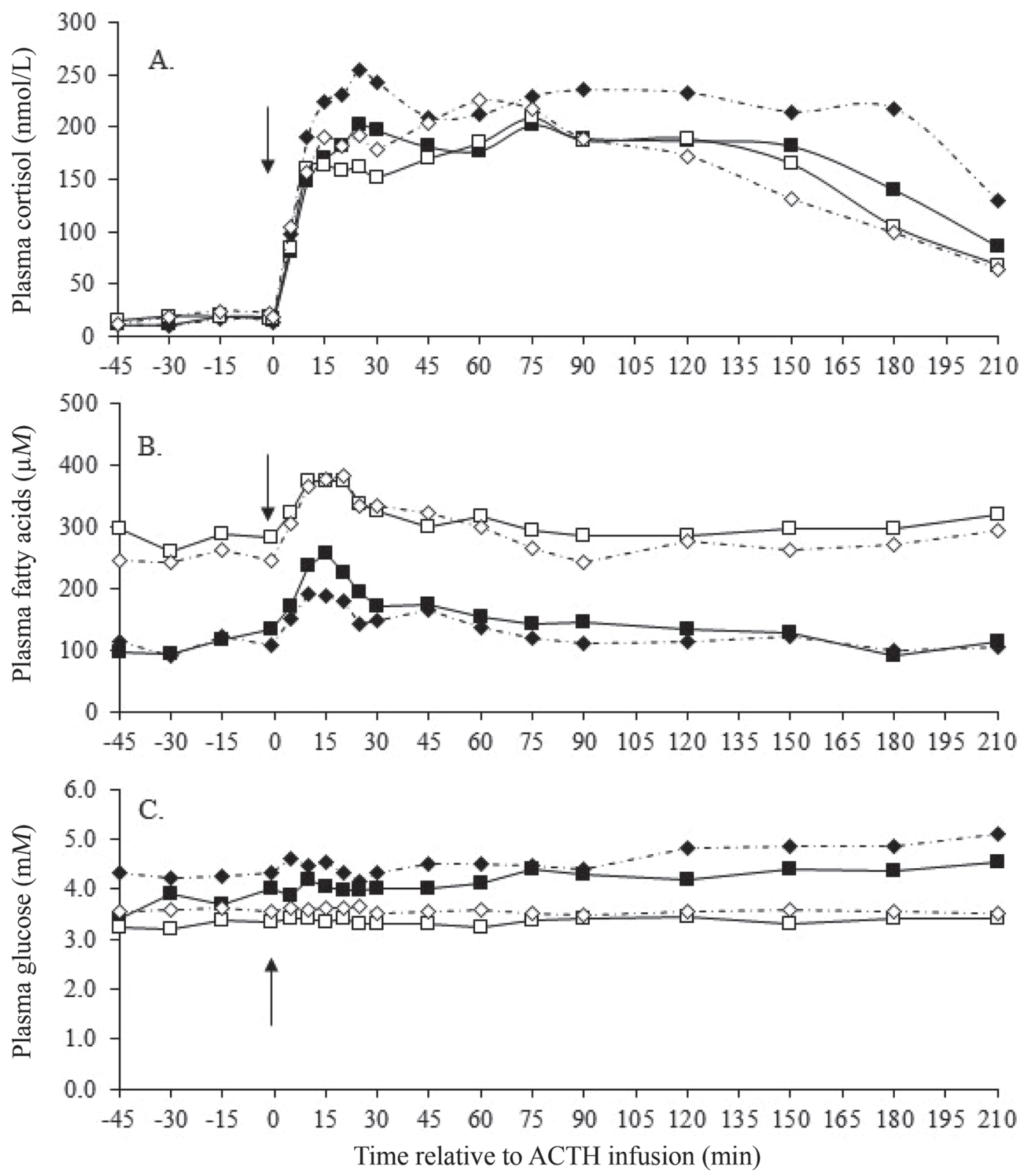

Figure 1. Plasma cortisol (A), fatty acids (B), and glucose (C) responses to an ACTH challenge $(2 \mu \mathrm{g} / \mathrm{kg}$ of BW) in dairy cows classified as low-calfhood residual feed intake (RFI; $\mathrm{n}=8$; RFI $=-0.83$ ) and high-calfhood RFI $(\mathrm{n}=8$; RFI $=0.69)$ based on phenotypic RFI measured during growth during midlactation [closed square, solid line for low-calfhood RFI ( $\mathbf{a})$ and closed diamond, dashed line for high-calfhood RFI $(\diamond)$ ] and the dry period [open square, solid line for low-calfhood RFI ( $\square$ ) and open diamond dashed line for high-calfhood RFI $(\diamond)$ ]. Arrow indicates time of ACTH infusion $(0 \mathrm{~min})$. Overall standard error of the difference for the effect of group $\times$ stage $\times$ time was 21.4 nmol/L for cortisol, $45.6 \mu M$ for fatty acids, and $0.29 \mathrm{~m} M$ for glucose. 

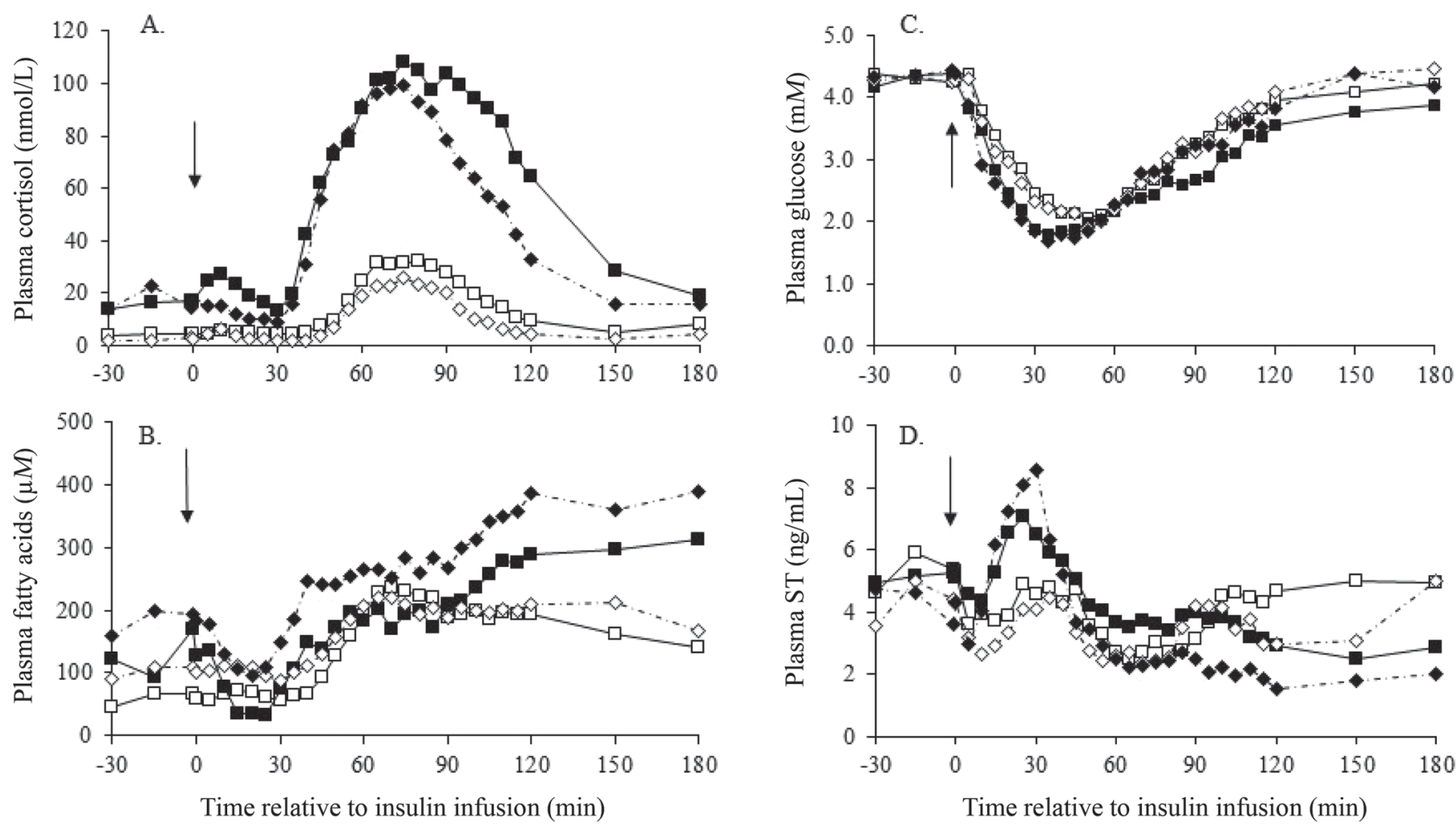

Figure 2. Plasma cortisol (A), fatty acids ( B), glucose (C), and somatotropin (ST; D) responses to an insulin challenge (0.12 U/kg of BW) in dairy cows classified as low-calfhood residual feed intake $(\mathrm{RFI} ; \mathrm{n}=8 ; \mathrm{RFI}=-0.83)$ and high-calfhood RFI $(\mathrm{n}=8 ; \mathrm{RFI}=0.69)$ based on phenotypic RFI measured during growth during midlactation [closed square, solid line for low-calfhood RFI ( $\mathbf{\square})$ and closed diamond, dashed line for high-calfhood RFI ( $\bullet$ ] and the dry period [open square, solid line for low-calfhood RFI $(\square)$ and open diamond dashed line for high-calfhood RFI $(\diamond)$ ]. Arrow indicates time of insulin infusion $(0 \mathrm{~min})$. Overall standard error of the difference for the effect of group $\times$ time $\times$ stage was $0.22 \mathrm{~m} M$ for glucose, $36.3 \mu M$ for fatty acids, $10.43 \mathrm{nmol} / \mathrm{L}$ for cortisol, and $1.01 \mathrm{ng} / \mathrm{mL}$ for ST.

were influenced by sample time, and were greater during midlactation compared with the dry period (Figure $3 \mathrm{~A} ; P<0.001)$. We observed an interaction such that mean plasma fatty acid concentration was greater in low-calfhood RFI cows in response to both the low and high epinephrine doses during the dry period, but we found no difference due to calfhood RFI in midlactation $(P<0.001)$.

The mean plasma glucose concentration increased in response to the high but not the low epinephrine dose and responses were greater during midlactation compared with the dry period (Figure 3B; $P<0.001$ ). We noted an interaction such that mean plasma glucose concentration in response to epinephrine was greater for low- compared with high-calfhood RFI cows during midlactation but not the dry period $(P=0.03)$.

\section{DISCUSSION}

Previous research suggests that RFI measured during growth is retained in lactating cattle (Macdonald et al., 2014; Pryce et al., 2015), mature (finishing) beef ani- mals (Herd and Arthur, 2009), in Limousin $\times$ Friesian heifers (Kelly et al., 2010), and in Charolais-crossbred steers (Crews et al., 2003). Although research is limited in dairy cattle, this collectively indicates that RFI is a consistent trait across different life stages. This is supported by our data, as demonstrated in Table 1, where feed-to-milk and feed-to-ECM ratios were lower in low- compared with high-calfhood RFI cows, with all other production parameters being similar between groups. However, the biological mechanisms underpinning differences in RFI are not well understood. The results of this experiment support our main hypothesis, that decreased HPA axis responsiveness, as measured by ACTH induced cortisol, is associated with low-calfhood RFI in dairy cows selected for divergent RFI as growing calves. This demonstrated reduction in cortisol response to ACTH in low-calfhood RFI cows is a novel finding in dairy cattle and suggests that a portion of the metabolic mechanisms that underpin efficiency are related to HPA axis responsiveness, as previously demonstrated in sheep (Knott et al., 2008, 2010) and pigs (Jenkins et al., 2013). 
The responses to ACTH observed in the present experiment are consistent with our first hypothesis that low-calfhood RFI cows would have a decreased HPA axis response. First, the low-calfhood RFI cows had a $15 \%$ lower overall plasma cortisol response to ACTH and a lower cortisol AUC from 0 to 30 min compared with high-calfhood RFI cows during midlactation. The cortisol response to ACTH is the most reliable parameter for assessing adrenal cortex function, whereby individual cortisol responsiveness to ACTH appears to be consistent (Verkerk et al., 1994). Thus, the lower cortisol response to ACTH in the low-calfhood RFI cows indicates a lower adrenal responsiveness than the high-calfhood RFI cows. Repeated exposure to acute stressors will inevitably prompt repeated cortisol responses and production losses may occur in response to the associated increase in energy consumption to mount this response. Conversely, repeated exposure to stressors, resulting in chronic stress, may also lead to adrenal fatigue or habituation and result in reduced responsiveness to ACTH (Wilcox et al., 2013). Further experiments are required to confirm that low-RFI dairy cattle are less adrenally responsive compared with high-RFI dairy cattle and to directly measure energy expenditure in response to HPA axis activation.

We speculated that a portion of the variation in RFI can be attributed to differences in HPA axis responsiveness, including variation in the cortisol response to ACTH. As RFI is phenotypically independent from production traits, it is thought to be indicative of metabolic differences between individual animals. Our results indicate a potentially greater proportion of dietary energy directed toward HPA-axis responsiveness in the high-RFI cows, contributing to a loss in overall efficiency. This is supported by data from Marett et al. (2017), who provide evidence to suggest variation in nutrient partitioning in cows of divergent calfhood RFI. In their experiment using a small group of multiparous cows selected for divergent RFI as calves, they showed that low-RFI cows partitioned a greater proportion of
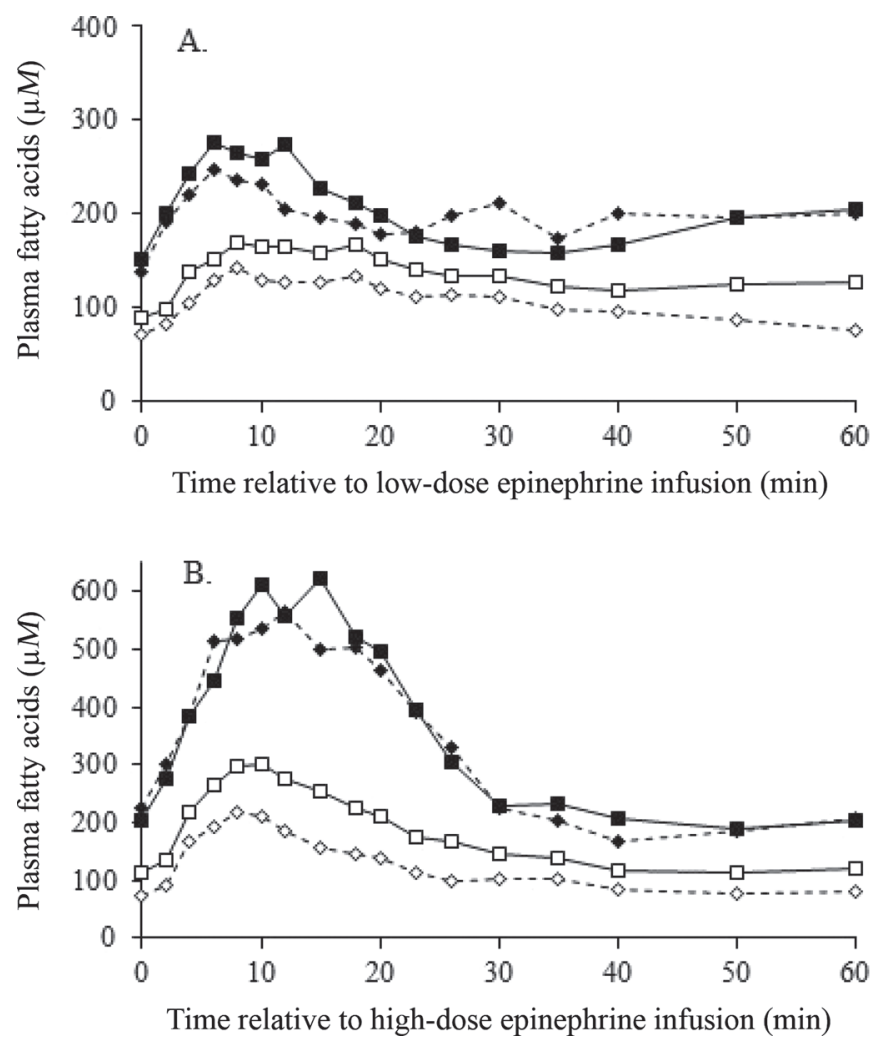
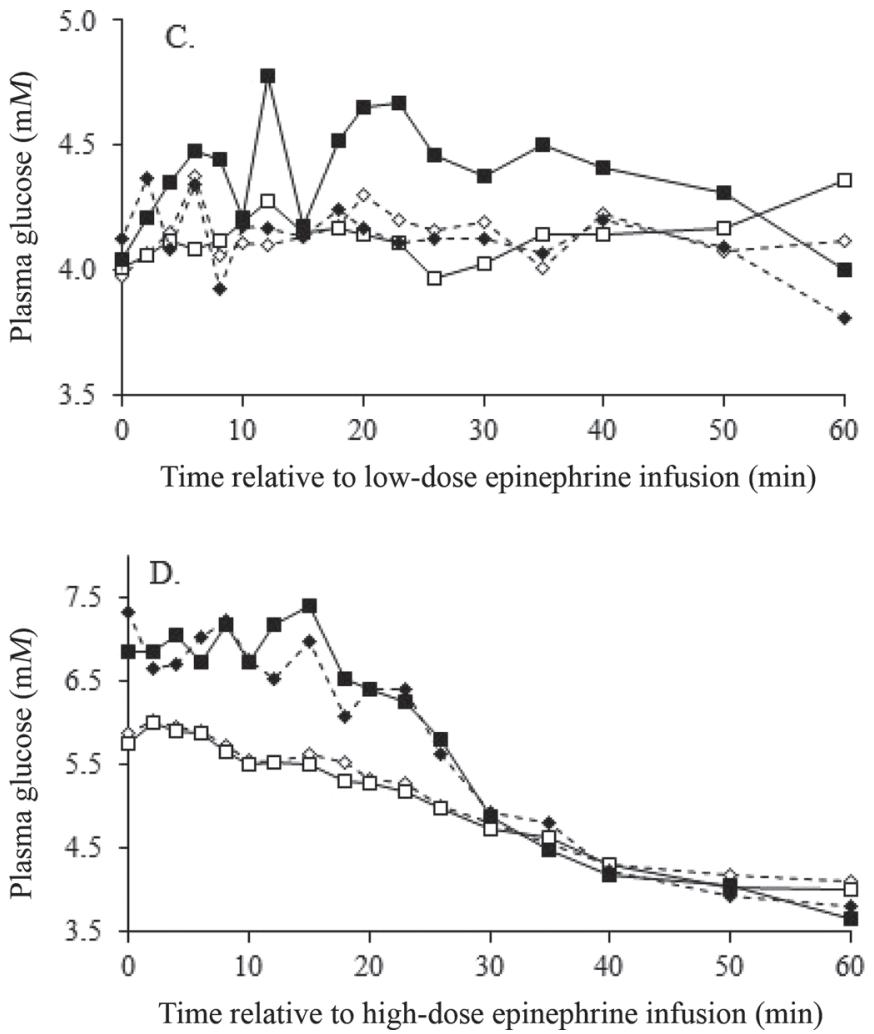

Figure 3. Plasma fatty acids $(\mathrm{A}=$ low, $\mathrm{B}=$ high $)$ and glucose $(\mathrm{C}=$ low, $\mathrm{D}=$ high $)$ responses to a low $(0.1 \mu \mathrm{g} / \mathrm{kg}$ of $\mathrm{BW})$ and high $(1.6 \mu \mathrm{g} /$ $\mathrm{kg}$ of BW) epinephrine dose, respectively, based on phenotypic residual feed intake (RFI) measured during growth during midlactation [closed square, solid line for low-calfhood RFI ( $\mathbf{\square})$ and closed diamond, dashed line for high-calfhood RFI ( )] and the dry period [open square, solid line for low-calfhood RFI $(\square)$ and open diamond dashed line for high-calfhood RFI $(\diamond)$ ]. Measures were obtained from dairy cows classified as low-calfhood RFI $(\mathrm{n}=8$; RFI $=-0.83)$ and high-calfhood RFI $(\mathrm{n}=8$; RFI $=0.69)$. Epinephrine infusion occurred at 0 min. Results are truncated at $60 \mathrm{~min}$ of the 120 -min challenge. The $P$-value for the effect of epinephrine dose was $<0.001$ for both plasma fatty acids and glucose responses. The overall standard error of the difference for fatty acids was $43.2 \mu M$ for the low dose and $45.4 \mu M$ for the high dose. The overall standard error of the difference for glucose was $0.41 \mathrm{~m} M$ for the low dose and $0.40 \mathrm{~m} M$ for the high dose. 
gross energy intake to milk and less to heat production than high-RFI cows.

Low-calfhood RFI cows had a greater initial cortisol response to insulin (AUC from 0-30 min) across both physiological states. This is consistent with the responses to ACTH observed in the present experiment and supports the findings of Knott et al. (2010) in sheep. The increase in plasma cortisol is in direct response to the exogenous insulin challenge initiating hypoglycemia and consequently stimulating the HPA axis and triggering the release of cortisol (Caraty et al., 1990). Insulin resulted in hypoglycemia, although we found no difference in the degree of hypoglycemia achieved (as demonstrated by the AUC) due to RFI. Similarly, plasma fatty acid AUC responses to insulin induced hyperglycemia were not influenced by RFI.

We found no measureable difference between the high- and low-calfhood RFI cows in their response to the low dose of epinephrine; this indicates little to no change in the sensitivity to catecholamines. However, the low-calfhood RFI cows had a greater plasma fatty acid response to the high dose of epinephrine, indicating a greater lipolytic responsiveness to epinephrine than the high-calfhood RFI cows. This supports our first hypothesis and suggests that low-calfhood RFI cows are more responsive to epinephrine than the highcalfhood RFI cows. Holstein-Friesian cows with high genetic merit for milk production exhibited a greater lipolytic response to an epinephrine challenge than those of low genetic merit (Kolver et al., 2001; Roche et al., 2009). Further, cows with a higher genetic merit for milk production have lower subcutaneous adipose stores and partition more energy toward the mammary gland for milk production (McNamara., 1989; Khan et al., 2013). Whereas RFI is not directly linked to genetic merit for milk production, a cow of low-RFI will require less feed to achieve a similar level of production compared with a cow with a higher RFI, and thus be more feed efficient.

Our results generally support our last hypothesis, that responses to the metabolic challenges will vary due to calfhood RFI during both lactating and nonlactating periods; however, plasma hormone and metabolite responses were less pronounced (with the exception of the plasma fatty acid response to $\mathrm{ACTH}$ ) during the dry compared with the midlactation period, which is consistent with other reports in lactating cows (Shayanfar et al., 1975; Kejela et al., 1978; Verkerk et al., 1994). Cows were more responsive to the high dose of epinephrine in terms of plasma fatty acid and glucose increases and AUC from 0 to 60 min during midlactation compared with the dry period. This was expected, as adipose tissue is more responsive to epinephrine during lactation to support lactation compared with the dry period (Bauman et al., 1985; McNamara, 1988; Bell and Bauman, 1997). The peak cortisol response to epinephrine did not differ due to physiological state. However, during midlactation, the cortisol response to ACTH was prolonged with a greater cortisol AUC from 0 to 210 min compared with the dry period. Evidence in nonlactating sheep suggests that basal cortisol concentrations in the nonstress conditions do not differ compared to those measured during lactation (Tilbrook et al., 2006). Others have demonstrated no difference in basal plasma glucocorticoids after parturition and in early lactation compared with the nonlactating and pregnant dairy cow (Kejela et al., 1978) or throughout the stages of lactation and pregnancy (Shayanfar et al., 1975). Conversely, Trevisi et al. (2009) demonstrated a greater basal cortisol concentrations in early compared with mid- and late-lactation cows, whereas the rise of cortisol in response to ACTH was greater in mid and late lactation. Our results are consistent with the adrenal cortex being more responsive during midlactation compared with the dry period, with no change in sensitivity.

Although our experiment used low numbers of cows given the intensive nature of the metabolic studies conducted, we demonstrated clear differences in the responsiveness to ACTH between cows selected for RFI as calves. These differences are important, as they highlight variation in the use of dietary and stored energy between cows of different RFI and physiological states. Additional studies utilizing behavioral and hormonal stressors in larger numbers of animals are warranted to further determine the role of HPA axis activation on the efficiency of energy utilization in dairy cattle. For example, similar methods to those applied to sheep by Knott et al. $(2008,2010)$ could be used to understand the roles of ACTH reactivity and body condition on metabolism and behavioral reactivity, which are suggested to contribute to feed efficiency in lactating and nonlactating dairy cattle. Finally, it is imperative that the potential relationship between dairy cattle health and RFI is explored to ensure that selection based on RFI does not increase disease susceptibility, particularly during lactation.

\section{CONCLUSIONS}

The results indicate that low-RFI cows (based on RFI measured during growth) have a lower cortisol response to an ACTH infusion than high-calfhood RFI cows, particularly during midlactation. Furthermore, low-calfhood RFI cows were more responsive to lipolytic signals induced by an epinephrine challenge, suggesting that low-calfhood RFI cows partition energy more readily away from storage in adipose tissue. These 
differences in HPA axis responsiveness likely contribute to the range of processes that together determine an individual animals phenotypic RFI. Additional studies utilizing larger populations are required to validate the present findings. Our results suggest HPA axis responsiveness as a trait might persist across an animal's life and lactation status. However, further research is required to explore these phenotypic relationships at varying stages of lactation, such as the transition period, to examine if relationships between efficiency and HPA axis responsiveness are upheld at all stages of lactation.

\section{ACKNOWLEDGMENTS}

The experiment was funded by the Dairy Futures Cooperative Research Centre (CRC), Australia.

\section{REFERENCES}

Archer, J. A., E. C. Richardson, R. M. Herd, and P. F. Arthur. 1999. Potential for selection to improve efficiency of feed use in beef cattle: a review. Aust. J. Agric. Res. 50:147-162. https://doi.org/ 10.1071/A98075.

Bauman, D. E., S. N. McCutcheon, W. D. Steinhour, P. J. Eppard, and S. J. Sechen. 1985. Sources of variation and prospects for improvement of productive efficiency in the dairy cow: A review. J. Anim. Sci. 60:583-592.

Bell, A. W., and D. E. Bauman. 1997. Adaptations of glucose metabolism during pregnancy and lactation. J. Mammary Gland Biol. Neoplasia 2:265-278. https://doi.org/10.1023/a:1026336505343.

Bocking, A. D., I. C. McMillen, R. Harding, and G. D. Thorburn. 1986. Effect of reduced uterine blood flow on fetal and maternal cortisol. J. Dev. Physiol. 8:237-245.

Boisclair, Y. R., K. B. Johnston, D. E. Bauman, B. A. Crooker, F. R. Dunshea, and A. W. Bell. 1997. Paradoxical increases of circulating nonesterified fatty acids in somatotropin treated cattle undergoing mild disturbances. Domest. Anim. Endocrinol. 14:251-262. https://doi.org/10.1016/s0739-7240(97)00021-0.

Breier, B. H., B. W. Gallaher, and P. D. Gluckman. 1991. Radioimmunoassay for insulin-like growth factor-I: solutions to some potential problems and pitfalls. J. Endocrinol. 128:347-357. https://doi.org/ 10.1677 /joe.0.1280347.

Caraty, A., M. Grino, A. Locatelli, V. Guillaume, F. Boudouresque, B. Contedevolx, and C. Oliver. 1990. Insulin-induced hypoglycemia stimulates corticotropin-releasing factor and arginine vasopressin secretion into hypophyseal portal blood of conscious, unrestrained rams. J. Clin. Invest. 85:1716-1721. https://doi.org/10.1172/ JCI114626.

Crews, D., N. Shannon, B. Genswein, R. Crews, C. Johnson, and B. Kendrick. 2003. Genetic parameters for net feed efficiency of beef cattle measured during postweaning growing versus finishing periods. Pages 125-128 in Proceedings of the American Society of Animal Science Western Section, Phoenix, AZ. Vol. 54. Am. Soc. Anim. Sci., Champaign, IL.

Dairy Australia. 2013. Cow Body Condition Scoring Handbook. Dairy Australia, Southbank, Victoria, Australia.

Downing, J. A., J. Joss, P. Connell, and R. J. Scaramuzzi. 1995. Ovulation rate and the concentrations of gonadotrophic and metabolic hormones in ewes fed lupin grain. J. Reprod. Fertil. 103:137-145. https://doi.org/10.1530/jrf.0.1030137.

Gluckman, P. D., J. J. Johnson-Barrett, J. H. Butler, B. W. Edgar, and T. R Gunn.. 1983. Studies of insulin-like growth factor-I and II by specific radioligand assays in umbilical cord blood. Clin. Endo- crinol. (Oxford) 19:405-413. https://doi.org/10.1111/j.1365-2265 1983.tb00014.x

Herd, R. M., and P. F. Arthur. 2009. Physiological basis for residual feed intake. J. Anim. Sci. 87(suppl):E64-E71. https://doi.org/10 $.2527 /$ jas.2008-1345.

Herd, R. M., V. H. Oddy, and E. C. Richardson. 2004. Biological basis for variation in residual feed intake in beef cattle. 1. Review of potential mechanisms. Aust. J. Exp. Agric. 44:423-430. https:// doi.org/10.1071/EA02220.

Jenkins, J., N. K. Gabler, L. Anderson, J. Dekkers, A. Johnson, and F. R. Dunshea. 2013. Evaluation of the responsiveness of swine divergently selected for feed efficiency to an exogenous adrenocorticotropin hormone (ACTH) challenge. Iowa State University Animal Industry Report. Vol. AS659, ASL R2814.

Johnson, M. M., and J. P. Peters. 1993. Technical note: An improved method to quantify nonesterified fatty acids in bovine plasma. J. Anim. Sci. 71:753-756.

Kejela, G., H. H. Head, C. J. Wilcox, and W. W. Thatcher. 1978. Adrenal responsiveness in pre- and postpartum dairy cows. J. Dairy Sci. 61:1736-1741. https://doi.org/10.3168/jds.S0022 $-0302(78) 83795-3$

Kelly, A. K., M. McGee, D. H. Crews, T. Sweeney, T. M. Boland, and D. A. Kenny. 2010. Repeatability of feed efficiency, carcass ultrasound, feeding behavior, and blood metabolic variables in finishing heifers divergently selected for residual feed intake1. J. Anim. Sci. 88:3214-3225. https://doi.org/10.2527/jas.2009-2700.

Khan, M. J., A. Hosseini, S. Burrell, S. M. Rocco, J. P. McNamara, and J. J. Loor. 2013. Change in subcutaneous adipose tissue metabolism and gene network expression during the transition period in dairy cows, including differences due to sire genetic merit. J. Dairy Sci. 96:2171-2182. https://doi.org/10.3168/jds.2012-5794.

Knott, S. A., L. J. Cummins, F. R. Dunshea, and B. J. Leury. 2008 Rams with poor feed efficiency are highly responsive to an exogenous adrenocorticotropin hormone (ACTH) challenge. Domest. Anim. Endocrinol. 34:261-268.

Knott, S. A., L. J. Cummins, F. R. Dunshea, and B. J. Leury. 2010. Feed efficiency and body composition are related to cortisol response to adrenocorticotropin hormone and insulin-induced hypoglycemia in rams. Domest. Anim. Endocrinol. 39:137-146.

Kolver, E., J. Roche, M. de Veth, and T. Mackle. 2001. Lipolytic response of New Zealand and overseas Holstein-Friesian dairy cows challenged with epinephrine. Pages $48-51$ in Proc. N. Z. Soc. Anim. Prod. Vol. 61. New Zealand Society of Animal Production, Christchurch, New Zealand.

Macdonald, K. A.. J. E. Pryce, R. J. Spelman, S. R. Davis, W. J. Wales, G. C. Waghorn, Y. J. Williams, L. C. Marett, and B. J. Hayes. 2014. Holstein-Friesian calves selected for divergence in residual feed intake during growth exhibited significant but reduced residual feed intake divergence in their first lactation. J. Dairy Sci. 97:1427-1435. https://doi.org/10.3168/jds.2013-7227.

Marett, L. C., S. R. O. Williams, B. J. Hayes, J. E. Pryce, and W. J. Wales. 2017. Partitioning of energy and nitrogen in lactating primiparous and multiparous Holstein-Friesian cows with divergent residual feed intake. Anim. Prod. Sci. 57:1499-1506. https://doi .org/10.1071/AN16476.

McNamara, J. P. 1988. Regulation of bovine adipose tissue metabolism during lactation. 4. Dose-responsiveness to epinephrine as altered by stage of lactation. J. Dairy Sci. 71:643-649.

McNamara, J. P. 1989. Regulation of bovine adipose tissue metabolism during lactation. 5. Relationships of lipid synthesis and lipolysis with energy intake and utilization. J. Dairy Sci. 72:407-418. https://doi.org/10.3168/jds.S0022-0302(89)79122-0.

Nieuwhof, G., J. A. M. Van Arendonk, H. Vos, and S. Korver. 1992 Genetic relationships between feed intake, efficiency and production traits in growing bulls, growing heifers and lactating heifers. Livest. Prod. Sci. 32:189-202.

Pryce, J. E., J. Arias, P. J. Bowman, S. R. Davis, K. A. Macdonald, G. C. Waghorn, W. J. Wales, Y. J. Williams, R. J. Spelman, and B. J. Hayes. 2012. Accuracy of genomic predictions of residual feed intake and 250-day body weight in growing heifers using 625,000 single nucleotide polymorphism markers. J. Dairy Sci. 95:2108-2119. 
Pryce, J. E., O. Gonzalez-Recio, G. J. Nieuwhof, W. J. Wales, M. P. Coffey, B. J. Hayes, and M. E. Goddard. 2015. Hot topic: Definition and implementation of a breeding value for feed efficiency in dairy cows. J. Dairy Sci. 98:7340-7350. https://doi.org/10.3168/ jds.2015-9621.

Roche, J. R., N. C. Friggens, J. K. Kay, M. W. Fisher, K. J. Stafford, and D. P. Berry. 2009. Invited review: Body condition score and its association with dairy cow productivity, health, and welfare. J. Dairy Sci. 92:5769-5801.

Roche, J. R., A. J. Sheahan, L. M. Chagas, D. Blache, D. P. Berry, and J. K. Kay. 2008. Long-term infusions of ghrelin and obestatin in early lactation dairy cows. J. Dairy Sci. 91:4728-4740. https:// doi.org/10.3168/jds.2008-1193.

Sapolsky, R. M., L. M. Romero, and A. U. Munck. 2000. How do glucocorticoids influence stress responses? Integrating permissive, suppressive, stimulatory, and preparative actions. Endocr. Rev. 21:55-89. https://doi.org/10.1210/edrv.21.1.0389.

Sechen, S. J., F. R. Dunshea, and D. E. Bauman. 1990. Somatotropin in lactating cows - effect on response to epinephrine and insulin. Am. J. Physiol. 258:E582-E588.

Selye, H. 1951. The general-adaptation-syndrome. Annu. Rev. Med. 2:327-342. https://doi.org/10.1146/annurev.me.02.020151.001551.

Shayanfar, F., H. H. Head, C. J. Wilcox, and W. W. Thatcher. 1975. Adrenal responsiveness in lactating Holstein cows. J. Dairy Sci. 58:870-878. https://doi.org/10.3168/jds.S0022-0302(75)84651-0.

Tilbrook, A. J., and I. J. Clarke. 2006. Neuroendocrine mechanisms of innate states of attenuated responsiveness of the hypothalamo-pituitary adrenal axis to stress. Front. Neuroendocrinol. 27:285-307. https://doi.org/10.1016/j.yfrne.2006.06.002.
Tilbrook, A. J., A. I. Turner, M. D. Ibbott, and I. J. Clarke. 2006. Activation of the hypothalamo-pituitary-adrenal axis by isolation and restraint stress during lactation in ewes: Effect of the presence of the lamb and suckling. Endocrinology 147:3501-3509.

Trevisi, E., R. Lombardelli, A. Minuti, and G. Bertoni. 2009. Adrenal responsiveness to a low-dose ACTH challenge in early and late lactating dairy cows. Ital. J. Anim. Sci. 8(Suppl. 2):661-663.

Trinder, P. 1969. Determination of glucose in blood using glucose oxidase with an alternative oxygen receptor. Ann. Clin. Biochem. $6: 24-25$.

Tyrrell, H. F., and J. T. Reid. 1965. Prediction of the energy value of cow's milk. J. Dairy Sci. 48:1215-1223. https://doi.org/10.3168/ jds.S0022-0302(65)88430-2.

Verkerk, G. A., K. L. Macmillan, and L. M. McLeay. 1994. Adrenal cortex response to adrenocorticotropic hormone in dairy cattle. Domest. Anim. Endocrinol. 11:115-123. https://doi.org/10.1016/ 0739-7240(94)90039-6.

Waghorn, G. C., K. A. Macdonald, Y. Williams, S. R. Davis, and R. J. Spelman. 2012. Measuring residual feed intake in dairy heifers fed an alfalfa (Medicago sativa) cube diet. J. Dairy Sci. 95:1462-1471. https://doi.org/10.3168/jds.2011-4670.

Wilcox, C. S., M. M. Schutz, M. R. Rostagno, D. C. Lay Jr., and S. D. Eicher. 2013. Repeated mixing and isolation: Measuring chronic, intermittent stress in Holstein calves. J. Dairy Sci. 96:7223-7233. https://doi.org/10.3168/jds.2013-6944.

Williams, Y. J., J. E. Pryce, C. Grainger, W. J. Wales, N. Linden, M. Porker, and B. J. Hayes. 2011. Variation in residual feed intake in Holstein-Friesian dairy heifers in southern Australia. J. Dairy Sci. 94:4715-4725. https://doi.org/10.3168/jds.2010-4015. 